\author{
Наталія Вербич \\ Інститут української мови НАН України \\ Київ \\ ORCID: 0000-0003-3373-6332; e-mail: nataljaverbich@ukr.net
}

\title{
Методологія експериментально-фонетичного дослідження діалектного мовлення
}

\begin{abstract}
Реферат: У статті описано методологію та методи дослідження інтонації діалектного мовлення. Закцентовано на проблемах, що постають перед експлораторами під час запису матеріалу, йдеться зокрема про технічні характеристики звукових файлів, питання підбору інформантів, можливості опрацювання зашумлених текстів. Джерельну базу формують власні записи автора, а також аудіозаписи з Українського діалектного фонофонду Інституту української мови НАН України. Особливу увагу приділено членуванню діалектної оповіді на окремі сегменти. Засвідчено відмінності між реальним звучанням діалектного мовлення і його сприйняттям під час слухового аналізу. Наголошено на необхідності використання спеціальних програм для аналізу звукового мовлення.
\end{abstract}

Ключові слова: експериментально-фонетичний аналіз, усне мовлення, діалектний текст, фраза, синтагма, пауза.

\begin{abstract}
The methodology of an experimental-phonetic study of dialect speech. The phonetics of Ukrainian dialects has long been an object of analyses. Researchers describe the structural originality of the speech, establishing the composition of the segmental units in different dialects, their significance to the phonological system of the dialect, systematizing knowledge about the manifestations and relationships of phonemes. In Ukrainian linguistics, dialect intonation remains unexplored. The reasons included the complexity of the methodology and the methodology of the analysis (from recording speech material to its direct processing).

As the title implies, the article describes the choice of methods and methodologies for research into the intonation of dialectal speech. Much attention has been devoted to the recording of speech, its technical descriptions and the selection of the informants. The article focuses on the features of segmentation of dialectal speech. This study shows the difference between a real sound file and its processing during an auditory analysis. The need is stressed to employ special software for analysing verbal material.
\end{abstract}

Key words: experimental-phonetic analysis, speech, dialectal text, phrase, syntagmas, pause.

В Інституті української мови НАН України понад пів століття функціонувала Лабораторія експериментальної фонетики. Спеціалізувалася вона на дослідженні надсегментного рівня усного мовлення. Співробітники порівняли інтонацію підготовленого та спонтанного мовлення, схарактеризували надсегментні особливості діалогу й монологу, просодичну реалізацію завершеності / незавершеності висловлення, інтонаційні моделі різних жанрів усного публічного мовлення тощо (Вербич 2011). Матеріалом для аналізу переважно були літературні варіанти української, російської, білоруської, французької, англійської та інших мов. 
В останні десятиліття помітно зріс інтерес до просодії діалектного мовлення. У романо-германській і західнослов'янській фонетиці висвітлено питання інтонації регіональних варіантів літературних мов, а також просодії окремих говірок. Описано інтонаційне оформлення фрази в певній говірці та зіставлено ці дані 3 просодією літературної мови, порівняно різновиди діалектної інтонації на матеріалі однієї мови, виявлено вплив просодії окремих територіальних говірок або соціолектів на загальнолітературний стандарт, установлено взаємозв'язок інтонаційних особливостей говіркового мовлення та регіональних варіантів літературної мови тощо.

Навіть звичайне прослуховування записів різних українських говірок також дає змогу виявити відмінності щодо ритмічної організації синтагми, розміщення фразових акцентів, темпорального та мелодичного оформлення висловлення. Окремі аспекти надсегментної організації діалектного мовлення розпрацьовувала у своїх роботах О.С. Біла, проаналізувавши акцентно-ритмічну структуру ізольовано вимовленого слова та цього самого слова в мовленнєвому потоці на матеріалі гуцульської, бойківської та покутсько-буковинської говірок (Белая 1984). Інтонаційні особливості комунікативних видів висловлення (розповіді, питання, спонукання) на матеріалі покутсько-буковинської говірки схарактеризувала В.С. Бузинська (1986). Особливості членування, а також характеристика різновидів пауз та їхнє функційне навантаження були об’єктом наших досліджень.

Констатуємо, що в українській лінгвістиці діалектна інтонація поки що залишається малодослідженим явищем насамперед через складність методики й методології аналізу (від запису мовленнєвого матеріалу до його безпосереднього опрацювання).

Найважливішою умовою експериментально-фонетичного дослідження є запис усного мовлення. Традиційно мовленнєвий матеріал для аналізу його акустичних параметрів записували в спеціально обладнаних студіях із застосуванням високоякісних приладів фіксації мовленнєвих сигналів. Головна мета експериментатора - мінімізувати вплив «зовнішніх» чинників (сторонні шуми, перешкоди). Це завдання ускладнюється в тих випадках, коли дослідник працює з мовленнєвим матеріалом, записаним у «польових» умовах. Необхідно чітко розмежувати ознаки, які характеризують мовлення реципієнта, та ознаки, сформовані під зовнішніми впливами. Прослуховування фонограм, отриманих під час діалектологічних експедицій, засвідчує, що такі зразки усного мовлення не завжди придатні для інструментального аналізу.

По-перше, під час запису текстів в умовах безпосереднього спілкування з інформантом «виникають труднощі технічного характеру: наявність сторонніх шумів, різний рівень мовного сигналу, залежний від ступеня віддаленості мовця від мікрофона, від гучності сигналу тощо» (Багмут, Борисюк, Олійник 1985, 7), що заважають об'єктивному експериментально-фонетичному аналізові таких фрагментів мовлення. По-друге, використання звукозаписувальної апаратури низької якості, призначеної лише для фіксації змісту розмови, зумовлює появу у звуковому файлі додаткових нелінійних та інтермодуляційних спотворень, що унеможливлює іiі подальше опрацювання.

Усі попередні дослідження українських фонетистів, присвячені аналізові акустичних характеристик спонтанного мовлення, проведено на матеріалах, записаних 
за спеціальними програмами в лабораторіях експериментальної фонетики, що було пов'язано з необхідністю одержати технічно високоякісні записи усних оповідей. Дослідники вважали, що мовлення дикторів під час фонетичних експериментів і за ситуацією, і за психологічними умовами мало відрізняється від кодифікованого варіанта літературної мови, записаного в умовах безпосереднього спілкування. Відомо, що досліджуючи сегментні й надсегментні особливості діалектного мовлення, фонетисти запрошували до студії звукозапису діалектоносіїв із різних регіонів України для отримання якісних матеріалів, однак пізніше від такої ідеї відмовилися. 3 одного боку, значні матеріальні витрати, пов'язані з такими експериментами, ускладнювали фіксацію достатнього для дослідження матеріалу. 3 другого боку, слуховий аналіз свідчив, що діалектне мовлення, записане в студійних умовах, не зовсім відповідає реальному побутуванню говірок передусім через психологічну неготовність діалектоносіїв до спілкування в зазначених умовах.

Розвиток інформаційних технологій у кінці XX - поч. XXI ст., поява спеціальних комп'ютерних програм для опрацювання звукових файлів уможливили окремі аспекти експериментально-фонетичного аналізу спонтанного мовлення, записаного під час безпосереднього спілкування з мовцями, ідеться, зокрема, про аналіз інтонації та просодії усного мовлення, часокількісних і частотних характеристик звуків і складів, виділених з потоку мовлення.

Одне з головних питань методики експериментального дослідження - підбір інформантів. Для фонетистів важливо підшукати інформантів віком від 20 до 50 років, які володіють орфоепічно правильною вимовою, вміють говорити перед мікрофоном, не мають вставних зубів, органічних і функціональних дефектів вимови тощо (Артемов 1956, 82). Для експлоратора-діалектолога важлива орієнтація на інформантів - мешканців сіл найстаршого віку, оскільки саме їхні свідчення дають якісно нову інформацію про говір, виявляють специфіку фонологічної та фонетичної системи діалекту (Мартинова 2003, 6), на їхньому мовленні найменшою мірою позначилися впливи літературної мови, тоді як мовлення молодших людей переважно зберігає лише окремі діалектні риси (Костина 2006, 78).

Із позицій методології експериментальної фонетики такі мовці не завжди є «надійними» інформантами, оскільки з віком голос людини змінюється. Це виявляється в зростанні його висоти, сповільненні артикуляції тощо. Такі модифікації спричинені зношеністю м’язів, зменшенням об'єму легень, погано вставленими зубними протезами, палінням. Серед головних вад мовлення діалектоносіїв старшого віку відзначимо, зокрема, шепелявість, неправильну артикуляцію звуків [c] i [3], які виникають через дефекти в будові щелеп і зубів або недоліки слуху, що не дає змоги контролювати власне мовлення; гугнявість, патологічна зміна тембру голосу та неправильне вимовляння звуків, зумовлене вадами піднебінно-глоткової завіси, викривленням носової перегородки. Часто в людей старшого віку внаслідок ослаблення рухових функцій мовленнєвого апарата утруднюється артикуляція окремих звуків (зокрема [p], [ш], [ж] та ін.). Безперечно, мовлення таких діалектоносіїв не буде інформативним в експериментально-фонетичних студіях. Але спілкуючись із представниками конкретної говірки, виявляємо людей старшого віку (від 70 років), мовлення яких виразне, яскраве, з чітким і правильним артикулюванням звуків. 
Записуючи матеріал для експериментально-фонетичного аналізу діалектного мовлення, потрібно вибирати інформантами представників говірки, які (за визначенням діалектологів) мають генеалогічне коріння в обраній для дослідження місцевості, проживають у ній без тривалого від’їзду, ізольовані від діалектоносіїв інших говірок; не мають професійної (вищої або середньої спеціальної) освіти; i (що важливо для фонетистів) є гарними оповідачами, не ніяковіють перед мікрофоном, мають бажання спілкуватися на різноманітні теми, відверті та незамкнуті під час розмови; а також мають чітку дикцію, зрозуміле бездефектне мовлення, яке можна легко розшифрувати.

Дослідження діалектів будь-якої мови починають із записів говіркового мовлення, які пізніше представляють як затранскрибовані тексти й описують відповідно до мети та завдань конкретних студій. Отже, ще одне важливе питання своєрідність представлення або, точніше, відтворення діалектного мовлення.

Доброю традицією стало унаочнення збірників текстів дисками зі звуковими файлами, які дублюють надруковане або доповнюють його новим матеріалом. Щодо письмового представлення діалектних оповідей (зокрема, зразки діалектних текстів у статтях і додатках до дисертацій або в окремих збірниках) помічено, що найчастіше затранскрибовані монологи не відтворюють реального мовлення діалектоносія на рівні його сегментнування, а є більшою або меншою мірою відредагованими варіантами діалектної розповіді.

Спостережено, що членування діалектних монологів грунтується насамперед на врахуванні смислових зв'язків у монологах та орієнтацію авторів на знання про основи сегментування писаного тексту. Адже відомо, що в кодифікованому усному мовленні (зокрема під час читання й виголошення підготовлених виступів) існує взаємозв'язок між синтаксичним і фонетичним членуванням. Однак важливо пам'ятати, що діалектне мовлення - це явище спонтанне, його граматика в широкому розумінні суттєво відрізняється від граматики писаного тексту. У діалектних оповідях зв'язок між синтаксисом, пунктуацією та паузами (як найважливішими маркерами членування) набагато складніший, ніж у кодифікованому усному тексті; це виявляється передусім в асиметрії синтаксичного й комунікативного членування. Унаслідок одночасності й синхронності процесів обдумування, планування й продукування мовлення кореляція зміст - форма часто порушується, окремі сегменти мовлення не пов'язані чіткими формально-граматичними зв'язками (межі фраз / синтагм «розмиті», їхнє просодичне оформлення не має однозначних делімітативних ознак).

Якщо в літературному підготовленому мовленні межі інтонаційного членування (і місця появи пауз) усередині фрази переважно збігаються з межами частин складного речення й синтаксично пов'язаних груп усередині простого, то особливість синтагмоподілу діалектного мовлення зумовлює головна ознака такого різновиду загальнонаціональної мови - спонтанність, що виявляється в породженні тексту в момент говоріння, одночасності мисленнєво-мовленнєвих процесів, коли мовець не має достатньо ні часу, ні можливості для попереднього докладного обмірковування думки.

У діалектній оповіді можуть функціонувати самодостатні однослівні синтаг-

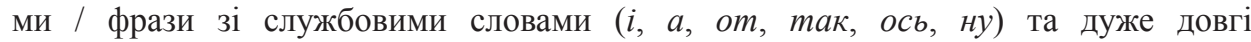




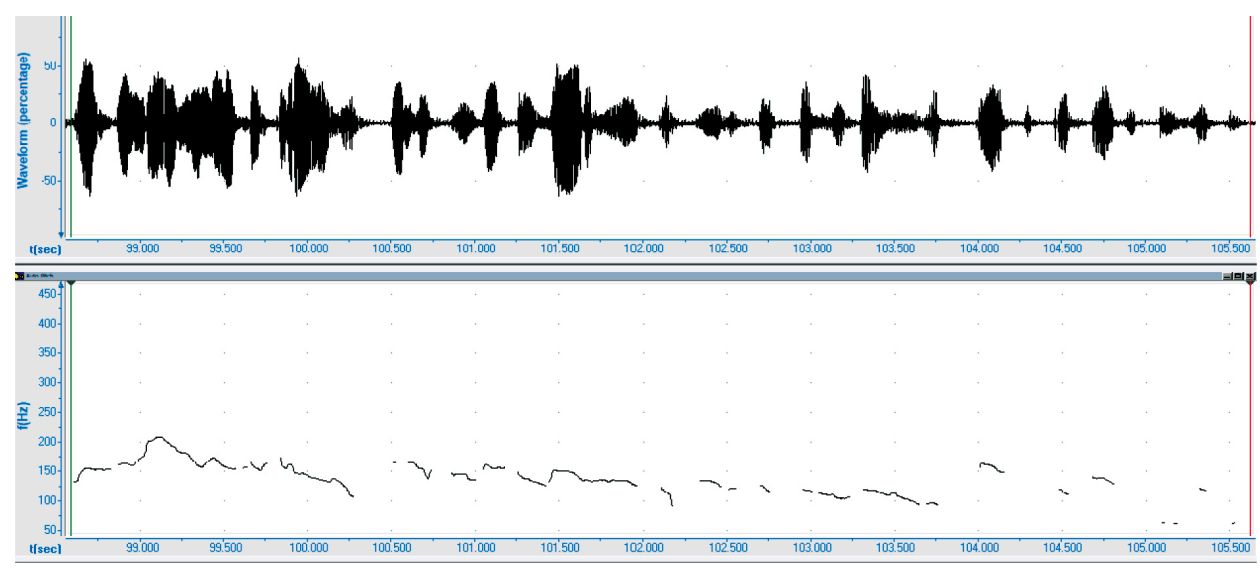

Рис. 1, Фрагмент мовлення: / йак $i$ ни́н'i наш укра́йіней' пі́де служи́ти у а́рмійу послу́жсит дес там на Да́л'н'ем Восто́к'е прихо́дит та й ўже тут / (Трк)

конструкції, що часом містять кілька частин складного речення або кілька окремих простих речень: / йак $і$ ни́н’i наш укра́йінец’ пі́де служитти у а́рмійу послуюжит дес там на Да́л'н'ем Восто́к'е прихо́дит та й ўже тут / ну н’іхто́ не пон'іма́йу н'іка́к не мо ўже ма́мі гово́рит то / (Трк); ну / $i$ вони́ притли / $i$ /м/ ба́т 'кові сказа́ли шоп подписа́вс'а ну він же ж ни міг та рука́ йака́ // (Гр); ну /е/ ну а ти де с'i mу вз'е́ла / йой ка́же там мен'í / оту́тка ба́би'а йе зо мноў ка́же але́ ууни ми над’у́тали очи тай не ви́джу // (Мл); тай там йакі́с' примо́ви ка́у шо / аби́ lel так йа с'i ў й’iм жи́т'i купа́йус' би так хло́пеи до ме́не приста́в би так мене́ л’уби́в йал би йа до це́го жита с'i тул'е́йу / так йа говор'y у m’iм жи́т'i // (Бб). Інструментальний аналіз підтверджує, що і однослівні, і багатослівні сегменти мають виразні цілісні інтонаційні контури, а отже є одним неподільним фрагментом мовлення (див. рис. 1).

Брак часу для обдумування спричиняє, з одного боку, тривіальне оформлення фрази, примітивізм та клішованість мовлення, часто заважає знайти найоптимальнішу, відшліфовану форму висловлювання. 3 другого боку, вибір мовленнєвих засобів полегшують процеси високої автоматизації застосування лексичних, граматичних і фонетичних засобів.

Необхідно пам'ятати, що діалектне мовлення структуроване не так, як підготовлене або читаний текст, межі окремих мовленнєвих елементів часто нечіткі, розмиті, тому таку оповідь можемо схарактеризувати як послідовність семантично значущих і акустично відокремлених блоків, пов'язаних між собою вільним (із семантичного та синтаксичного боку) зв'язком під час переривчастого, розірваного мовлення, або ж тісним зв'язком - під час плинного, логічного усного мовлення (див. попередні приклади). Підгрунтям синтагматичного членування є орієнтація на семантично-паузальну основу (див. докл. Вербич 2015; 2017).

У логіко-семантичній структурі діалектного монологу може бути чимало обмовок, самовиправлень, еліптичних конструкцій, спостерігаємо перебудову 
щойно висловленої думки, невиправдане багатослів'я, не досить чіткі синтаксичні конструкції, появу чималої кількості слів-зв'язок, повторів, конструкцій-кліше, слів-паразитів, надмірну кількість вигуків, вагання під час пошуку потрібного слова: / $i$ да́жи йа ка́жди го го із /u-u/ сво́йy хаз'а́йкойy / у горо́d’i с шу /e/ каза́ли

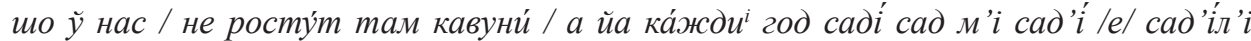
з ж'інкойу / i / на два́йат' c'óме /e-е/ c'інт'абра́ / ие наш пр 'істо́л'ни пра́зн'ік / Здв 'їж'ен'е / от / ў нас с'ігда́ кавуни́ були́ св'їжийе // (ТЛ); / i ка́жут та дити́на /е/ ма́ма / йійі m'i дити́н'i дайе́ гро́ші та й ка́же / то д’іўчинка́ булла / йой ти мо /е/ йак ти с'а назива́йеш а вона́ ка́же / та йа так $i$ так с’а назива́йу // (Мл); /

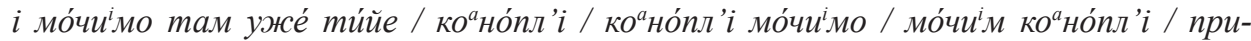
клада́йом ус'а́ким бурйано́м / н'е бурйано́м / a lel калу́ч':ем / шобп оани н'е збубн 'ували / (Рд). Діалектологи, транскрибуючи оповіді, часто пропускають, не фіксують такі елементи, хоча саме вони $є$ надійними ознаками кваліфікації усного тексту як спонтанного.

Під час експериментально-фонетичного аналізу ми встановили, що синтагмоподіл, маркером якого є граматична (здебільшого реальна) пауза, зафіксована в передбачуваному місці на межі окремих синтаксичних одиниць, частин складного речення, переважає насамперед у тих сегментах мовлення, де діалектоносій розповідає про буденні речі, побут, господарство, історію населеного пункту, звичаї, обряди тощо: / йаг ўже підросла́ / $i$ / ходи́ла ўже ў колго́сn на робо́ту / $i$ /ey/ вози́ли йа́кос' допі́р най так ни вмійу / а то с кін'ми / вес' час була́ / $i$ вози́ли зирно́ // (Гр); / зго́да так с'и начина́йе / с кіл'кинач’’ат’óх чолові́ків / $i$ на m’i зго́ді / йе й горі́лка / йе за́куска / i пита́йуm' / за по́ле // йакшчó тазда́ замі́жний / кусо́чки то́йі земл'í побі́л'ще да́си' / то хоч д’'іуччина й пога́на тай відда́си' // а коли́ / а коли́ по́л'а ме́нш'е то́йі земл'i / то дїуччну i гарн'їчу трудн'ішч'е відда́ти // (Нб); / Акришо́ра потому́-y / назива́лас'е / шчо /ум/ и’а р'ічка А́кра / то йе А́кра р'ічка ų’a / i nо m’ǐ p’iụ':i пішла́ на́зва / Акришо́ра // (Бб). Інтонацію таких фрагментів аудитори кваліфікують як унормовану, чітку, плавну. Відповідно, і такі затранскрибовані уривки мають найменше відхилень від запису-оригіналу під час відтворення членування.

Розповідь про особливо значущі для діалектоносія події підвищує рівень експресії оповіді, що спричиняє збільшення кількості семантичних (психологічних, видільних, емоційних, емфатичних) пауз i, відповідно, дрібніший поділ фрази на синтагми. Крім цього, підвищення експресивності тексту або його фрагментів часто зумовлює появу відрізків мовлення, які не можна однозначно співвіднести з синтаксичними одиницями - реченням, словосполученням, і схарактеризувати як змістово завершені через наявність гезитаційних явищ (еліптичних конструкцій, повторів, уточнень, пауз вагання), що руйнують смислову та фонетичну єдність тексту: / а / участко́ві / у нас буў / nіm час /ви-ев/ вїии́ / чого́ він де оста́вс'а шо він тут уц сел'í / $i$ до одно́йі уудови́ він так йак то / приста́ў / ну л’iт йому́ мо́же було́ / до підис'ати́ таки́і d’a / ну со́рок пйат' отаки́й во / ну не мо́жу на́віт' йа тобі́ на ко́го сказа́ти йаки́й був з здо / таки́й плечи́стий здоро́вий д’а́d 'ко / на н'о́го m'і́ко було́ подиви́тис'а / то то ууже / ну н'ічо́го ў сві́m'i ууже так не бойа́лас'а йак то́го участко́вого здава́лос'а шо то ўже бу́дут' би́ти там не зна́ти шо / i він так поза́d’i cтойím' / ди́виų'a на то́йе ўс'o // (Гр); / а сіл' 
y нас пойави́лас'а / знайшли́ л’ýdе /e/ y /u/ під л’іса́ми / під го́рами / де течým /e/ но́ри / i m’i но́ри le/ значи́m омива́йуm /е/ омива́йут значи́т ие так назива́йес'а / c’iл' така́ le/ камйана́ / а ў нас назива́йуm руб // (ВК). Саме в таких випадках діалектологи найчастіше «по-своєму» сегментують оповідь, орієнтуючись не на реальне інтонаційне оформлення звукового фрагмента, а підлаштовуючись під свої знання про членування читаного тексту.

Отже, кожна діалектологічна експедиція з метою фіксації матеріалу для експериментально-фонетичних студій передбачає кілька етапів. Спілкуючись із людьми, варто відзначити для себе «потрібних» мовців (ідеться насамперед не стільки про лексичне, стилістичне багатство мовлення того чи того діалектоносія, скільки про адекватну для подальшого інструментального аналізу вимову).

Безперечно, підбір інформантів потребує опрацювання чималої кількості оповідей для виявлення оптимальних текстів для конкретного дослідження. Найкращою умовою $є$ наявність кількох записів від одного мовця, отриманих тим самим експериментатором упродовж тривалого часу.

Для експериментально-фонетичного дослідження надсегментних особливостей усного мовлення є потреба записувати не лише монологи, але й діалоги як первинну форму реального втілення мови (не про розмову експериментатора та діалектоносія, а про діалоги самих носіїв говірки). До такої роботи варто залучати людей, які самі є представниками записуваної говірки, або ж мати змогу бути присутнім під час бесіди кількох діалектоносіїв. Такі тексти зібрати складніше, ніж розповідь-монолог, але в інформативному плані вони значно цінніші для подальшого аналізу, бо дають змогу схарактеризувати мовлення людини з усіма його лінгвальними та позалінгвальними особливостями.

Важливою умовою письмового відтворення реального діалектного монологу чи діалогу є відмова від орієнтації на кодифіковану літературну норму, зокрема редагування діалектної оповіді за зразками писемного тексту.

\section{Скорочення}

Бб - с. Бабинопілля Косівського р-ну Івано-Франківської обл.

ВК - с. Великий Ключів Коломийського р-ну Івано-Франківської обл.

Гр - с. Грибовиця Іваничівського р-ну Волинської обл.

Мл - с. Мельнич Жидачівського р-ну Львівської обл.

Нб - с. Небилів Рожнятівського р-ну Івано-Франківської обл.

Рд - с. Рудьки Чорнобильського р-ну Київської обл.

ТЛ - Товстий Ліс Чорнобильського р-ну Київської обл.

Трк - с. Турка Коломийського р-ну Івано-Франківської обл. 


\section{Література}

Артемов В.А. [Artemov V.A.] (1956), Экспериментальная фонетика [Jeksperimental'naja fonetika], Москва.

Багмут А.Й., Борисюк I.В., Олійник. Г.П. [Bagmut A.J., Borysjuk I.V., Olijnyk. G.P] (1985), Інтоначія спонтанного мовлення [Intonacija spontannogo movlennja], Київ.

Белая A.C. [Belaja A.S.] (1984), Акиентно-ритмическая структура слова в южно-западных говорах украинского языка [Akcentno-ritmicheskaja struktura slova $v$ juzhno-zapadnyh govorah ukrainskogo jazyka], Черновцы.

Бузинськая B.E. [Buzinskaja V.E.] (1986), Интонационная система (интонация фразы) в покутско-буковинском говоре (экспериментально-фонетическое исследование): автореф. дис. ... канд. філол. наук [Intonacionnaja sistema (intonacija frazy) v pokutskobukovinskom govore (jeksperimental'no-foneticheskoe issledovanie): avtoref. dis. ... kand. filol. nauk.], Ужгород.

Вербич H.C. [Verbych N.S.] (2011), Фонетичний фонд Інституту украӥнської мови НАН України: історія та перспективи розвитку [Fonetychnyj fond Instytutu ukrainskoi movy NAN Ukrainy: istorija ta perspektyvy rozvytku], «Українська мова», № 3, с. 3-8.

Вербич H.C. [Verbych N.S.] (2015), Особливості сегментування діалектного мовлення: звуковий текст vs хрестоматія [Osoblyvosti segmentuvannja dialektnogo movlennja: zvukovyj tekst vs hrestomatija], «Мовознавство», № 5, с. 21-29.

Вербич H.C. [Verbych N.S.] (2017), До питання про макросегментацію діалектного текcmy [Do pytannja pro makrosegmentaciju dialektnogo tekstu], «Мовознавство», № 1, c. $57-63$.

Костина Л.Ю. [Kostina L.Ju.] (2006), Современные носители говора: критерии отбора [Sovremennye nositeli govora: kriterii otbora], [в:] Русские говоры: вчера, сегодня, завтра, Тамбов.

Мартинова Г. [Martynova G.] (2003), Середньонаддніпрянський діалект. Фонетика і фонологія [Seredn'onaddniprjans'kyj dialekt. Fonetyka i fonologija], Черкаси. 